\title{
Microwave-accelerated processing of coral tissue histology
}

Carlos Toledo-Hernández ${ }^{1 \dagger^{*}}$, Irma I Torres-Vázquez ${ }^{2 \dagger}$ and José L Serrano-Vélez ${ }^{2}$

*Correspondence: c_toledo_hernandez@yahoo.com

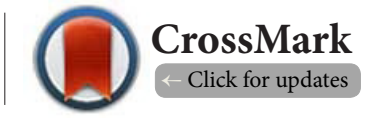

'These authors contributed equally to this work.

'Department of Biology, University of Puerto Rico-Río Piedras, San Juan, Puerto Rico.

${ }^{2}$ Biological Imaging Group (BIG), University of Puerto Rico-Río Piedras, San Juan, Puerto Rico.

\begin{abstract}
Background: Microwave technology has revolutionized histological processing by reducing processing time and improving tissue integrity. We describe the first microwave-accelerated tissue processing procedure for healthy and diseased tissue fragments of two species of corals: the gorgonian Gorgonia ventalina and the scleractinian Acropora cervicornis.
\end{abstract}

Methods: Fourteen tissue samples from sea fans (eleven healthy and three diseased), and one tissue sample from a healthy $A$. cervicornis, were decalcified and processed using microwaves. Histological slices were stained using hematoxylin and eosin and immunostained using an antibody against Aspergillus.

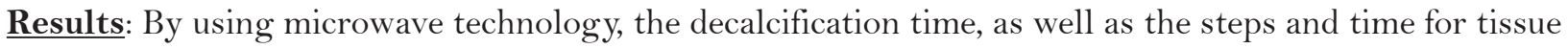
processing were significantly reduced while maintaining the integrity of the tissue.

Conclusions: This technique accelerates the chemical processing of coral tissue, while providing high quality and optimal resolution of histological sections.

Keywords: Histology, microwave, tissue processing, coral diseases

\section{Introduction}

Although the basics of tissue processing for microscopic examination remained unchanged during the early decades of the twentieth century, the advent of automation of dehydration, clearing, and infiltration processes during the 1940s added consistency to labor intensive and tedious procedures, not only simplifying the routine but also significantly reducing the time of processing from 48 or more hours to 22 to 28 hours [1-3]. First used in 1970, automated microwave processing technology has brought even greater improvement to histological procedures, and has been used across a wide spectrum of histological methods, including tissue fixation [4], decalcification and tissue processing (as shown here) [5], and staining for light and electron microscopy [6]. A major advantage of microwave energy is the reduction in turn-around time of slide completion. Processing tissue with traditional technology required 12 to 15 steps and took at least 9 hours [6]. In contrast, microwave processing reduces protocols to 4 to 5 steps that are immensely simplified and require significantly less time. Moreover, microwave processing provides vastly improved quality and resolution [7].
Microwave technology has rarely been used for histology of invertebrates. Non-variable wattage microwaves designed for cooking have been used for fixation of bivalve mollusk tissues [8], tissue dehydration of flatworms [9], tissue fixation and dehydration of tunicates [10], and for partial tissue decalcification of scleractinian corals [11]. Histologically-related studies of corals, including the field of coral diseases, have never used microwave technology for tissue processing. However, there is an urgent need to develop new tools to better describe and diagnose diseases affecting corals. Currently, most diseases of corals are diagnosed based on macroscopic characteristics [12]. This lack of concise and objective demonstration of histopathological features has fueled the debate regarding the structural features of healthy and diseased corals.

Here we present a histopathological protocol for coral using microwave technology that reduces the turn-around time of completion of microscope tissue slides, while maintaining the structural, cellular, and protein integrity of processed tissues, required to accurately describe and diagnose coral diseases. Moreover, we show that the protocol is amenable for fluorescence immunostaining by using an antibody 
Toledo-Hernández et al. Journal of Histology \& Histopathology 2014, http://www.hoajonline.com/journals/pdf/2055-091X-1-7.pdf

against Aspergillus, a common fungus known to affect coral's health. Therefore, our results are remarkably relevant to the growing field of coral diseases and can be extended to many other studies where fast, efficient methodologies and the maintenance of structural properties of evaluated tissues are required.

\section{Methods}

\section{Tissue collection and fixation}

Eleven healthy and three diseased tissue samples between $10.0-49.0 \mathrm{~mm}^{2}$ and with an average thickness of $2 \mathrm{~mm}$ were collected from specimens of the Caribbean sea fan Gorgonia ventalina. For this study, "healthy" is defined as sea fans that had no lesions, no purpling, and no overgrowth by fouling organisms. "Diseased" is defined as coral with dead tissue surrounded by a purpled halo. Additionally, one fragment between $4-5 \mathrm{~mm}$ in thickness and $2.5 \mathrm{~mm}$ in diameter was collected from a healthy scleractinian staghorn coral (Acropora cervicornis). The tissue samples were collected under permit (Puerto Rico Department of Natural Resources permit number 04-IC-051 issued to Carlos Toledo-Hernández). Immediately after collection, tissue samples were fixed for 1 hour in a modified Karnovsky's fixative (2.5\% glutaraldehyde (Electron Microscopy Sciences, Hatfield, PA) and 2\% paraformaldehyde (Sigma Aldrich, St. Louis, MO) diluted in filtered seawater) at room temperature [13]. Following fixation, tissue samples were rinsed 3 times (10 min each) in filtered seawater.

\section{Gorgonian and scleractinian coral tissue sample decalcification}

Gorgonian and scleractinian coral tissue samples were transferred to a decalcifying solution $(100 \mathrm{~g}$ ethylenediamine tetraacetic acid [EDTA] (Fisher Scientific, Waltham, MA), 10g $\mathrm{NaOH} / \mathrm{L}$ filtered seawater, $\mathrm{pH}$ 7.4) and placed in a LabPulse ${ }^{\mathrm{TM}}$ Microwave Tissue Processor (H 2850, Energy Beam Sciences, CT). Sea fan fragments between 10 to $20 \mathrm{~mm}^{2}$ were decalcified for $20 \mathrm{~min}$, while larger fans fragments (e.g., $<20 \mathrm{~mm}^{2}$ ) and the A. cervicornis fragment were decalcified for $40 \mathrm{~min}$ (Table 1). Decalcification was determined to be completed when no sclerites (calcium carbonate spines) were observed on the gorgonian sample surface, and the calcium carbonate skeleton was dissolved from the scleractinian sample. Preliminary experiments were done using different power levels of the microwave and reagent volumes to determine the optimal microwave settings for coral tissue (data not shown). For the results presented in this report, tissues were processed at $40^{\circ} \mathrm{C}$ for $20-40 \mathrm{~min}$ at a working power of $80 \%$ (720 watts). Note that the microwave power level for decalcification and tissue processing was set significantly higher (720 watts) than the power level that normally has been suggested (250-500 watts) [14]. The overall results suggested that at constant temperature, low volume and a high power level (720 watts), the decalcification process and tissue processing were accelerated without detrimentally affecting the integrity
Table 1. Steps, with volumes, temperatures, and times required for histological processing using microwave technology.

\begin{tabular}{lllll}
\hline \multicolumn{5}{c}{ Histological processing using microwave technology } \\
\hline Step & Solutions & Vol. $(\mathrm{ml})$ & Temp $\left({ }^{\circ} \mathbf{c}\right)$ & Time $($ min $)$ \\
\hline 1 & Decal-solution & 300 & 40 & $20-40$ \\
2 & Ethanol 95\% & 500 & 40 & 4 \\
3 & Ethanol 95\%/100\% & 500 & 40 & 4 \\
& 2-Propanol & & & \\
4 & 100\% 2-Propanol & 500 & 40 & 4 \\
5 & 2-Propanol/Paraffin & 500 & 80 & 10 \\
6 & Paraffin vacuum & -- & 60 & 30 \\
\hline
\end{tabular}

of the tissues. Therefore, the temperature is controlled by the volume of the reagent, and independent of the power level setting of the microwave.

\section{Gorgonian and scleractinian coral tissue sample processing}

Following decalcification, gorgonian and scleractinian coral tissue samples were washed in filtered seawater twice (10 min each). Then, tissues were placed in the microwave for dehydration in a sequence of $95 \%$ ethanol (Fisher Scientific, Waltham, MA, 95\% ethanol: 100\% isopropanol (2-propanol hereafter) [Fisher Scientific, Waltham, MA], and cleared in 100\% 2-propanol. Each step lasted $4 \mathrm{~min}$ and temperature was set to $40^{\circ} \mathrm{C}$. Next, tissue samples were kept in the microwave for infiltration in a 1:1 solution of melted paraffin and 2-propanol under vacuum for $10 \mathrm{~min}$ at $60^{\circ} \mathrm{C}$ (Table 1). A second round of infiltration was performed with $100 \%$ melted paraffin under vacuum for $30 \mathrm{~min}$ at $60^{\circ} \mathrm{C}$. During the infiltration process, a sheet of PolarHeat ${ }^{\mathrm{TM}}$ (Energy Beam Sciences, CT) was used to convert microwave energy to heat, resulting in an increase in diffusivity of the paraffin through the tissue [14].

\section{Sectioning and hematoxylin and eosin (H\&E) staining} Thin sections $(4-5 \mu \mathrm{m})$ from gorgonian and scleractinian coral tissue were obtained using a rotary microtome (model 820; American Optical, Buffalo, NY). Sections were affixed to subbed-glass slides (chrome alum-gelatin coating solution: $50.0 \mathrm{~g}$ gelatin (Mallinckrodt, St. Louis, MO) and $5.0 \mathrm{~g}$ chromium potassium sulfate (Mallinckrodt, St. Louis, MO) in $1 \mathrm{~L}$ distilled deionized water.

Sections were deparaffinized with Histo-Clear twice, $(30 \mathrm{~s}$ each, National Diagnostics, Charlotte, NC), re-hydrated through a descending series of ethanols (95\%-70\% ethanol each for 30 s), washed in distilled deionized water (2X each 30 s), stained in Harris hematoxylin (C.I. \#75290, Sigma Aldrich, St. Louis, MO) solution for $1 \mathrm{~min}$, washed in running tap water for 1 $\mathrm{min}$, differentiated in Scott solution ( $10 \mathrm{~g}$ sodium bicarbonate; $2 \mathrm{~g}$ magnesium sulfate in $1 \mathrm{~L}$ distilled deionized water; [15]) for $30 \mathrm{~s}$, and washed in running tap water again for $1 \mathrm{~min}$. Bluing was done using $0.2 \%$ ammonia water for $30 \mathrm{~s}$ to $1 \mathrm{~min}$. 


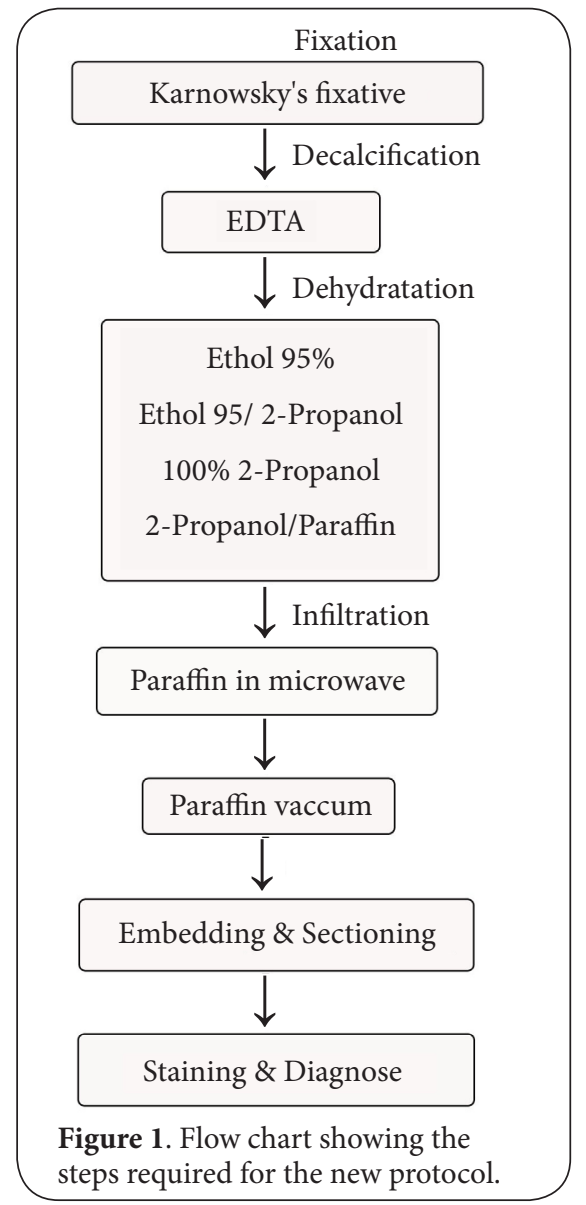

Sections were washed in running tap water for $5 \mathrm{~min}$; rinsed in 95\% alcohol (10 dips); counterstained in eosin Y (C.I. \#45380, National Aniline and Chemical Company, Buffalo, NY) solution for $30 \mathrm{sec}$ to $1 \mathrm{~min}$; dehydrated through $95 \%$ alcohol and 2 changes of absolute alcohol, 2 min each; cleared in Histo-Clear ( $2 X$ each for $5 \mathrm{~min}$ ); and coverslipped using Permount (VWR, Radnor, PA), a xylene based mounting medium.

\section{Immunohistochemistry}

For fluorescence immunohistochemistry, thin tissue sections $(5 \mu \mathrm{m})$ from healthy gorgonian coral were deparaffinized and hydrated through a descending series of ethanols (explained previously). Sections were permeabilized in $0.05 \%$ Triton X-100 (Sigma Aldrich, St. Louis, MO) for 15 min at room temperature. Then, tissue sections were rinsed in filtered seawater and incubated for 1 hour at room temperature in a blocking solution $(0.05 \%$ Triton X-100; $3 \%$ of normal goat serum; Jackson ImmunoResearch, West Grove, PA) in filtered seawater to prevent non-specific binding. After blocking, the tissue sections were rinsed with filtered seawater for $5 \mathrm{~min}$ and then incubated with a rabbit polyclonal primary antibody (1/500 diluted in blocking solution) against Aspergillus (Abcam, Cambridge, MA) at $4^{\circ} \mathrm{C}$ for 24 hours. Next, tissue sections were rinsed with filtered seawater for $5 \mathrm{~min}$ and immediately after, to prevent any endogenous fluorescence, tissue sections were blocked with $0.1 \%$ sodium borohydrate for 30 mins. Tissue sections were rinsed again with filtered seawater for $5 \mathrm{~min}$ and incubated for 2 hours at room temperature with Alexa Fluor $546^{\circledR}$ (Invitrogen, Eugene, OR) goat anti-rabbit secondary antibody (1/200 diluted in blocking solution) (Life Technology, Carlsbad, CA). Finally, tissue sections were washed twice (30 $s$ each) in filtered seawater and then labeled with Alexa Fluor 488 Phalloidin (Life Technology, Carlsbad, CA) for 5 min, rinsed again in filtered seawater ( $2 \mathrm{X}$ each $30 \mathrm{~s})$, and nuclei were stained with TO-PRO- $3^{\circledR}(1 / 500$ diluted in filtered seawater; Life Technology, Carlsbad, CA). Control slides were prepared precisely as described but utilizing the primary antibody only. Additional controls utilizing secondary antibodies only, were also performed. No immunohistochemical labeling was performed on A. cervicornis.

\section{Image acquisition}

Tissue sections were observed using appropriate filter sets for Alexa 546, phalloidin 488, and TO-PRO- $3^{\circledR}(642 / 661 \mathrm{~nm})$ in a Nikon Eclipse 800 (E800) optical microscope equipped with the modular Nikon C1 Plus laser scanning confocal system that is fully controlled by Nikon Elements AR (NISO) software. The E800 is equipped with differential interference contrast (DIC) and 10X Plan Fluor (N.A. $=0.30), 20 X$ Plan Fluor (N.A. $=0.45$ ), 40X Plan Fluor (N.A. $=0.65), 60 X$ S Fluor with correction collar ring (N.A. $=0.85)$, and 100X Plan Apo Oil immersed (N.A.=1.40) objectives. Images were acquired with a QImaging Retiga Exi camera (QImaging, Canada) with color filter. Image calibration and measurements were performed using Nikon NIS-Elements. Adobe Photoshop CS4 was used for figure plate preparation.

\section{Results}

The methods described in this report provided high quality longitudinal and cross tissue slides from corals (e.g., polyps). For instance, a longitudinal section of a sea fan polyp retracted into its calyx, with 4 extended tentacles surrounding the mouth is shown in Figure 2a. Although an artifact is observed in the separation of the basal tissue from the axial skeleton, this artifact is also frequently observed on histological preparations of octocoral using conventional techniques $[16,17]$. In fact, the microwave technique seems to minimize this effect. A cross sectional view of a polyp showing the mouth surrounded by 8 hollow radial chambers lined by gastrodermal tissue is also observed (Figure 2b). Many minute mesoglea openings surrounding the polyp are shown, some of which have spindle-like shapes [18]. These openings are lacunae remaining after sclerites were decalcified. In addition, another cross sectional view of a polyp shows a mouth surrounded by 8 tentacles filled with gastrodermal tissue (Figure 2c), each of which are separated by a septum also lined with gastrodermal tissue (Figure 2d).

Healthy coenenchyme (tissue between polyps) of sea fan and associated tissues and cells were also successfully 


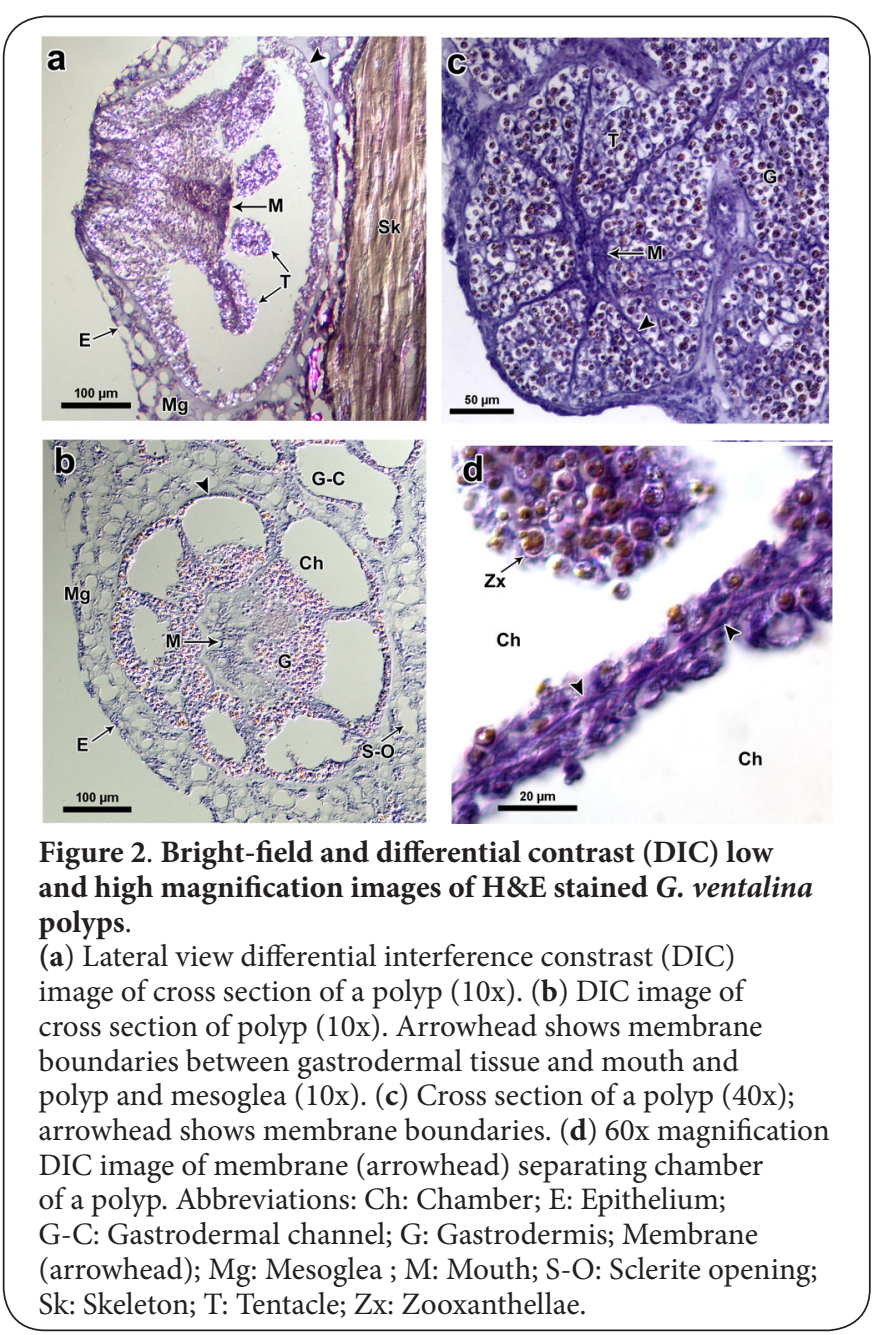

preserved and readily defined at low (Figure 3a) and high magnification (Figures $\mathbf{3 b}$ and $\mathbf{3 c}$ ). An epithelium ranging in thickness from 29 to $37 \mu \mathrm{m}$ is clearly observed separating the external environment from the gastrodermal tissue (Figures 3a and 3c). Within the gastrodermal tissue, round zooxanthellae ranging from 5 to $7 \mu \mathrm{m}$ in diameter are surrounded by vacuoles within host cells (Figure $\mathbf{3 b}$ ). In the mesoglea, sclerite openings are shown, surrounded by sclerocytes with round basophilic positive nuclei ranging in diameter from 3 to $6 \mu \mathrm{m}$ (Figure $3 \mathrm{c}$ ).

The new protocol is also useful for describing the cytology of diseased tissues. For instance, the characteristic features of diseased sea fan tissue: a complete absence of epithelium, broken mesoglea, and gastrodermal channels with their zooxanthellae outside their host gastrodermal cells are readily observed (Figure 4a). Hyphae-like structures surrounded by skeletal material as well as capsules, spores, and filamentouslike structures are also observed within the diseased tissue (Figures $\mathbf{4 b}$ and $\mathbf{4 d}$ ).

Additionally, the use of the accelerated microwave procedure assures the antigenicity of proteins, enabling us to perform fluorescence immunohistochemistry. For instance, Figure 5
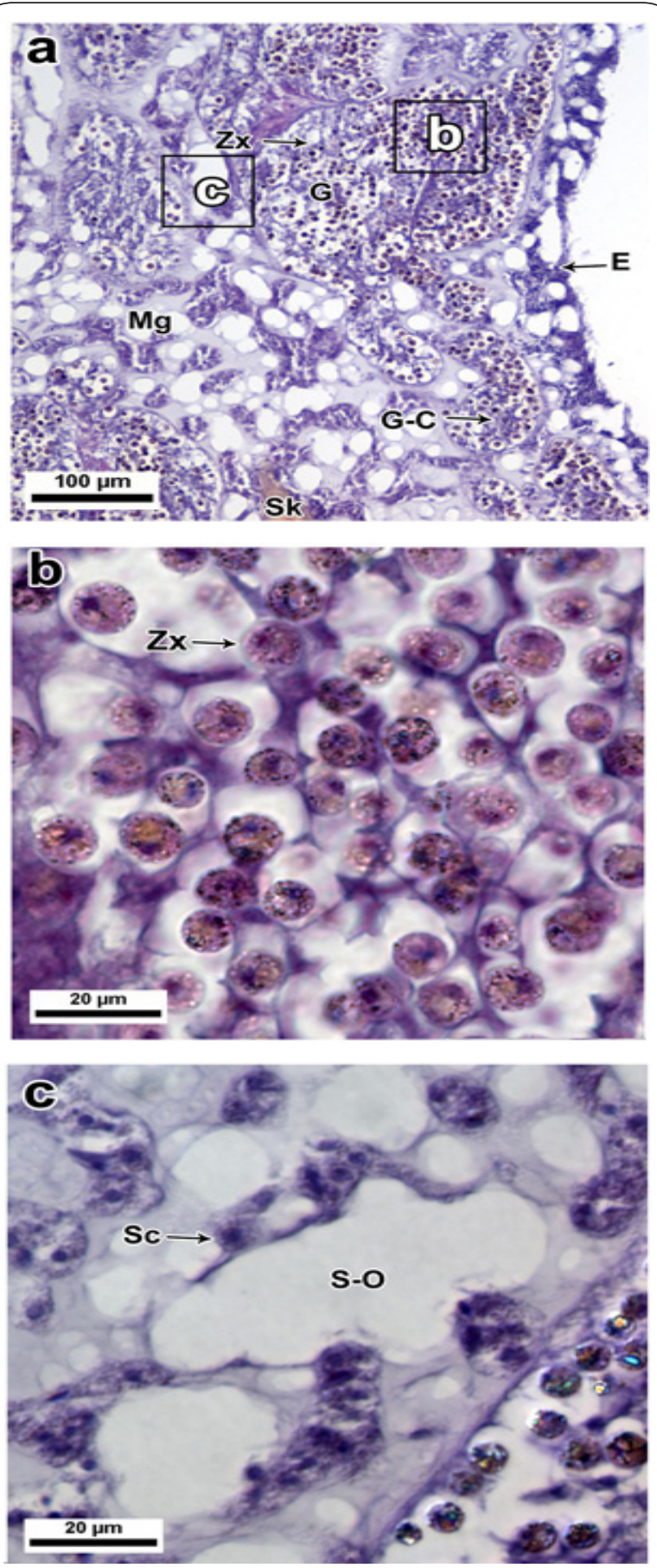

Figure 3. Bright-field low and high magnification images of healthy $H \& E$ stained coenenchyme tissue from $G$. ventalina.

(a) Healthy coenenchyme (10x). (b) Magnified view of Figure 4a showing rounded zooxanthellae encaged in vacuoles within the gastrodermis (100x oil immersion). (c) Magnified view of Figure 4a showing sclerite scarring and amoebocyte-like cells within the mesogleal tissue (60x oil immersion). Abbreviations: Sc: Sclerocytes-like cells; E: Epithelium; G-C: Gastrodermal channel; G: Gastrodermis; Mg: Mesoglea; S: Sclerite opening; Sk: Skeleton; Zx: Zooxanthellae. 

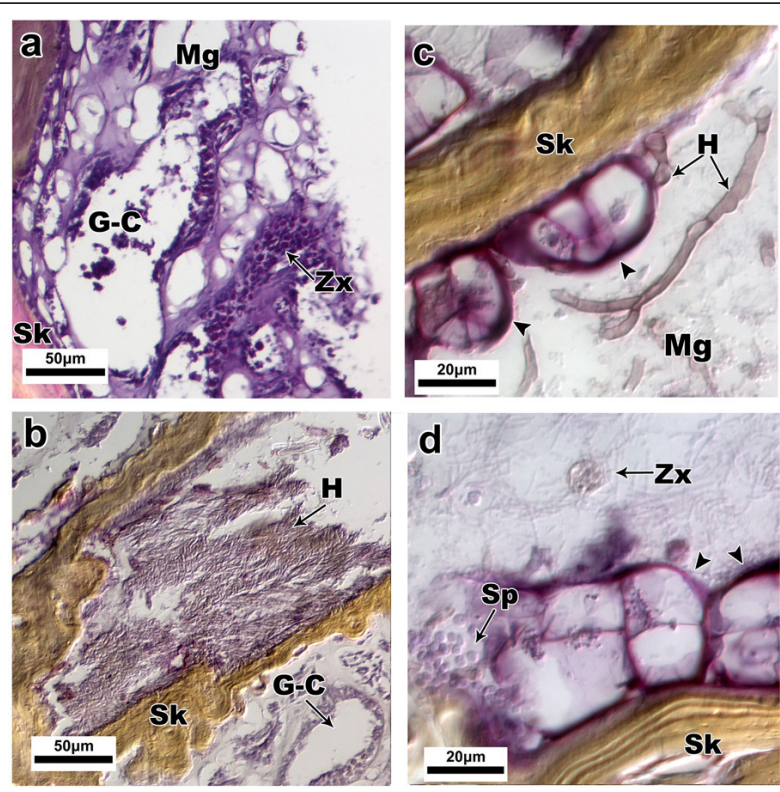

Figure 4. Bright-field images of H\&E stained diseased tissue from $G$. ventalina.

(a) Disrupted gastrodermal and mesogleal tissue (40x). (b)

Hyphae-like structures within the axis (40x). (c) Capsulelike structures (arrowheads) and fungal hyphae within the mesogleal tissue (60x oil immersed). (d) Capsule-like structures (arrowheads), spore-like cells, and zooxanthellae within mesoglea (60x oil immersed). Abbreviations: G-C: Gastrodermal chamber; H: Hyphae-like structures; Mg: Mesoglea; Sk: Skeleton; Sp: Spore-like structures; Zx: Zooxanthellae.

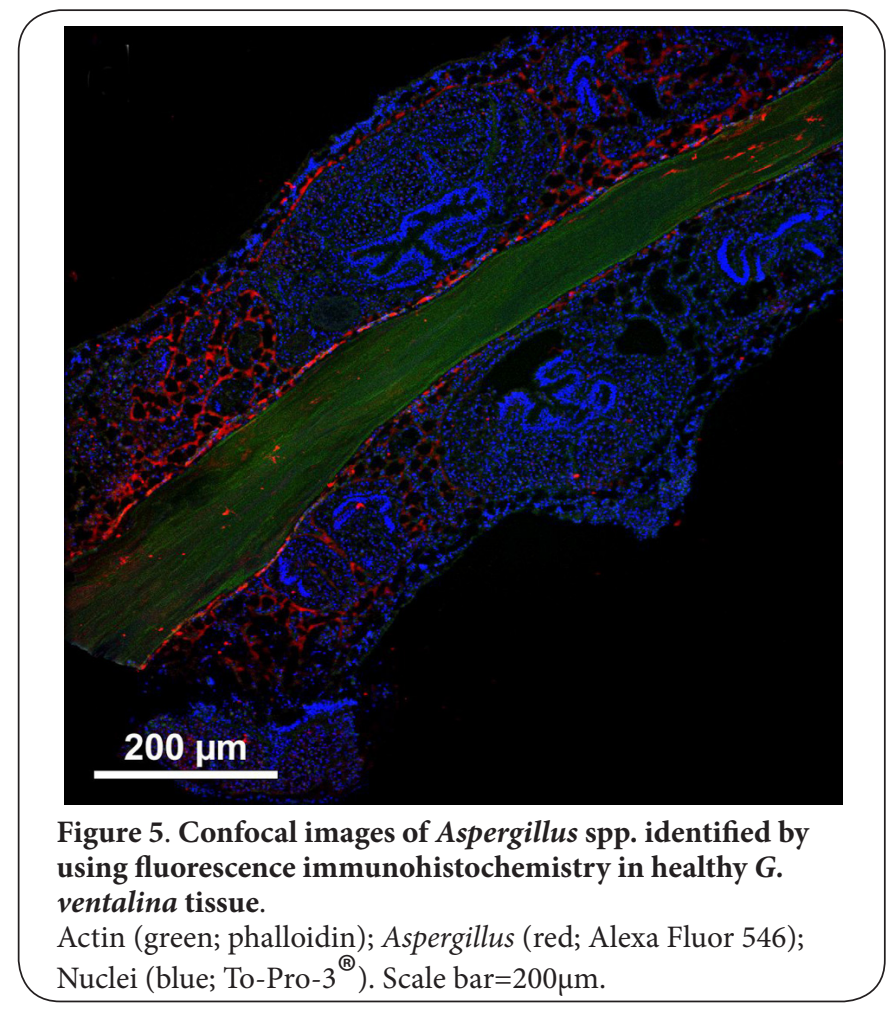

shows immunohistochemistry staining of a healthy sea fan tissue. Filaments of actin are primarily detected on the axial skeleton, whereas Aspergillus spp. is detected across the coenenchyme, bordering the polyps, and the axial skeleton. Nuclei are detected throughout the cells found across coenenchyme and polyps. Moreover, this result adds further evidence supporting the argument that fungi and in particular Aspergillus fungi are common to healthy sea fans [19-22].

As with gorgonians, this technique can also be used, with excellent results, on scleractians coral. For instance, Figure 6 shows tentacle epithelium of a healthy A. cervicornis. Numerous spirocyst across the epithelia are observed, while junction of mesoglea and myoepithelial cells are seemingly right underneath the epithelium.

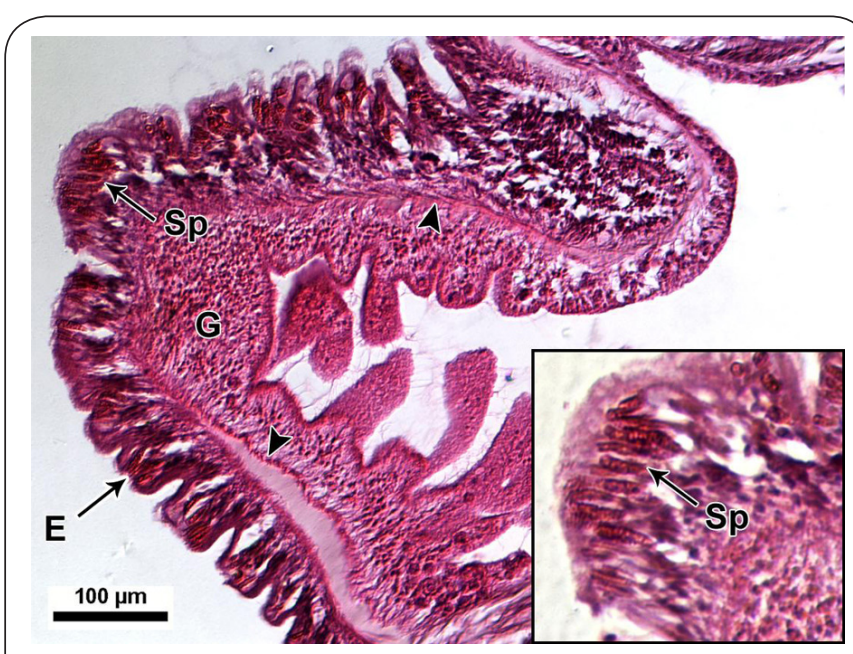

Figure 6. Bright field images of healthy H\&E stained $A$. cervicornis tissue.

Epithelium and gastrodermal tissue (20x). Complex interface of epithelial cells and mesoglea (arrow heads). Insert:

Magnification of epithelium and gastrodermal tissue (40X). Abbreviations: E: Epithelium; G: Gastrodermis; Sp: Spyrocstlike cells.

\section{Discussion}

Fourteen $G$. ventalina tissue samples ( 11 healthy and 3 diseased) and one healthy A. cervicornis were collected, fixed, decalcified dehydrated, embedded with paraffin, sliced, stained and prepared for light microscopy examination in approximately 5 hours (Figure 1 and Table 1). This constitutes the shortest time ever reported for a cnidarians histopathology study. In contrast, common procedures of coral histopathology take several days to complete tissue slices for light microscopic examination. For example, the average time of tissue fixation in gorgonians is 28 hours, with times ranging from 12-48 hours [23-28]. We reduced the fixation time to 1 hour. Similarly, decalcification time in previous studies ranged between 12 to 94 hours with EDTA $[\mathbf{2 4 , 2 6 , 2 9 ]}$ or 12 hours in ascorbic acid [28] at room temperature. In this study, tissue decalcification with 
Toledo-Hernández et al. Journal of Histology \& Histopathology 2014,

http://www.hoajonline.com/journals/pdf/2055-091X-1-7.pdf

the microwave oven took between 20 to 40 minutes (Table 1). Fragments between 10 to $20 \mathrm{~mm}^{2}$ were decalcified in $20 \mathrm{~min}$, while larger fragments (e.g., $<20 \mathrm{~mm}^{2}$ ) were decalcified in 40 $\mathrm{min}$. Standard procedures of tissue processing generally take 9 hours, using 7 washes of alcohols and several washes of clearing solutions, i.e., xylene [23]. We reduced tissue processing to 1.47 hours, while at the same time reducing the treatments of alcohol and their volumes for tissue dehydration to 2 , and substituting 2-propanol for xylene in the step of tissue clearing (Table 1). Unlike xylene, 2-propanol does not cause tissue samples to shrink or harden after clearing, and 2-propanol is less toxic to humans than xylene $[1,30,31]$. Furthermore, by substituting 2-propanol for xylene we improved the immunohistochemical staining of cells (Figure 6).

\section{Conclusion}

This technique not only accelerated the chemical processing of tissue, but also provided sections of high histological quality and resolution and, thereby, the capacity to distinguish between tissues and structures that are in close proximity. The microwave-accelerated tissue processing procedure also has several advantages over the conventional methods. First, it is versatile, as bright-field microscopy, immunohistochemistry and electron-microcopy (data not shown) can be conducted with the same equipment and tissue preparations. In addition, with minor modification, it can be used for other corals or invertebrates. Second, it is safer than the conventional method, because the reagents used with it are less toxic than those generally used $[1,30,32]$. Third, it is more cost efficient than the conventional method because it significantly reduces the number of steps and volumes of reagents used. Lastly, in contrast to the conventional method, microwave-accelerated processing is less time consuming: it takes approximately 5 hours to complete, as opposed to the 72 to 96 hours of the conventional method.

Additionally, in light of the current decline of corals due in part to diseases [33], this methodology may improve our understanding about their etiologies. Most coral diseases, including aspergillosis of gorgonian and white band syndromes (WBS) in acroporid corals, are diagnosed almost exclusively based on the macroscopic manifestation of the disease. However, macroscopic diagnoses of coral diseases may cause confusion and misinterpretation when different pathogenic agents induce similar macroscopic responses to the coral host. Yet, this technique should improve our capacity to diagnose these diseases accurately and rapidly, further improving our understanding of coral diseases, and thus our ability to effectively respond to them.

\section{Competing interests}

The authors declare that they have no competing interests.

Authors' contributions
\begin{tabular}{|l|c|c|c|}
\hline Authors' contributions & CTH & IIRV & JLSV \\
\hline Research concept and design & $\checkmark$ & $\checkmark$ & -- \\
\hline Collection and/or assembly of data & $\checkmark$ & -- & $\checkmark$ \\
\hline Data analysis and interpretation & $\checkmark$ & $\checkmark$ & $\checkmark$ \\
\hline Writing the article & $\checkmark$ & $\checkmark$ & $\checkmark$ \\
\hline Critical revision of the article & $\checkmark$ & $\checkmark$ & $\checkmark$ \\
\hline Final approval of article & $\checkmark$ & $\checkmark$ & $\checkmark$ \\
\hline Statistical analysis & $\checkmark$ & $\checkmark$ & $\checkmark$ \\
\hline
\end{tabular}

\section{Acknowledgement}

The authors would like to thank Dr. E. Rosa-Molinar for his unconditional support and suggestions throughout all stages of this work as well as unlimited access to tissue preparation and imaging resources. Drs. J. Taylor and J.E. García-Arrarás, and Paul Furumo for editing. The authors also thank Drs. A.M. Sabat, P. Bayman, M.G. Domínguez-Bello, P. Yoshioka and J. Torres for their comments and suggestions. We, also thank C.P. Ruiz for field assistance. This study was partially supported by MH-086994 (ERM) and NSF-0964114 (ERM).

Publication history

EIC: Giuseppe Musumeci, University of Catania, Italy.

Received: 09-Apr-2014 Final Revised: 26-Jul-2014

Accepted: 28-Aug-2014 Published: 16-Sep-2014

\section{References}

1. Buesa RJ and Peshkov MV. Histology without xylene. Ann Diagn Pathol. 2009; 13:246-56. | Article | PubMed

2. Morales AR, Nassiri M, Kanhoush R, Vincek V and Nadji M. Experience with an automated microwave-assisted rapid tissue processing method: validation of histologic quality and impact on the timeliness of diagnostic surgical pathology. Am J Clin Pathol. 2004; 121:528-36. | Article | PubMed

3. Leong AS. Microwaves and turnaround times in histoprocessing: is this a new era in histotechnology? Am J Clin Pathol. 2004; 121:460-2. | Article I PubMed

4. Mayers CP. Histological fixation by microwave heating. J Clin Pathol. 1970; 23:273-5. | Article | PubMed Abstract | PubMed Full Text

5. Boon ME, Wals-Paap CH, Visinoni FA and Kok LP. The two-step vacuummicrowave method for histoprocessing. Eur J Morphol. 1995; 33:349-58. I PubMed

6. Morales AR. Comparative usefulness of standard and microwave assisted tissue processing methods. Histologic. 2002; 35:40-46.

7. Giberson RT, Demaree RS, Jr. and Nordhausen RW. Four-hour processing of clinical/diagnostic specimens for electron microscopy using microwave technique. J Vet Diagn Invest. 1997; 9:61-7. | Article | PubMed

8. Berg CJ and Adams NL. Microwave fixation of marine invertebrates. J Exp Mar Biol Ecol. 1984; 14:195-199. | Article

9. Hooge MD and Smith III JPSs. New Acoels (Acoela, Acoelomorpha) from North Carolina. Zootaxa. 2004; 442:1-24. | Pdf

10. Cavalcante MC, de Andrade LR, Du Bocage Santos-Pinto C, Straus AH, Takahashi HK, Allodi S and Pavao MS. Colocalization of heparin and histamine in the intracellular granules of test cells from the invertebrate Styela plicata (Chordata-Tunicata). J Struct Biol. 2002; 137:313-21. | Article | PubMed

11. Goldberg WM. Feeding behavior, epidermal structure and mucus cytochemistry of the scleractinian Mycetophyllia reesi, a coral without tentacles. Tissue Cell. 2002; 34:232-45. | Article | PubMed

12. Pollock FJ, Morris PJ, Willis BL and Bourne DG. The urgent need for robust coral disease diagnostics. PLoS Pathog. 2011; 7:e1002183. | Article | PubMed Abstract | PubMed Full Text 
Toledo-Hernández et al. Journal of Histology \& Histopathology 2014, http://www.hoajonline.com/journals/pdf/2055-091X-1-7.pdf

13. Karnovsky MJ. A formaldehyde-glutaraldehyde fixative of high osmolarity for use in electron microscopy. J. Cell. Biol. 1965; 27:137A-138A.

14. Madden VJ. Microwave-Accelerated decalcification: Useful method for research and clinical laboratories. In Giberson RT, Demaree RS Jr. (Eds.), Microwave Techniques and Protocols. 2001; 101-122. | Article

15. Humason GL. Animal tissue techniques: 1967; 428.

16. Nonaka M, Nakamura M, Tsukahara M and Davis-Reimer J. Histological examination of precious corals from the Ryukyu Archipelago. J. Mar. Biol. 2012. | Article

17. Petes LE, Harvell CD, Peters EC, Webb MAH and Mullen KM. Pathogen compromise reproduction and induce melanization in Caribbean sea fans. Mar. Ecol. Prog. Ser. 2003; 264:167-171. | Pdf

18. Bayer F. The shallow water Octocorallia of the West Indian Region. A manual for Marine biologists. 1961; 257-262.

19. Toledo-Hernández C, Bones-González A, Ortiz-Vázquez, Sabat AM and Bayman P. Fungi in the sea fan Gorgonia ventalina: diversity and sampling strategies. Coral Reefs. 2007; 26:725-730. | Article

20. Toledo-Hernández C, Zuluaga-Montero A, Bones-González A, Rodríguez JA, Sabat AM, Bayman P. Fungi in healthy and diseased sea fans (Gorgonia ventalina): is Aspergillus sydowii always the pathogen? Coral Reefs. 2008. | Article

21. Zuluaga-Montero A, Toledo-Hernández C, Rodríguez JA, Sabat AM and Bayman P. Spatial variation in fungal communities isolated from healthy and diseased sea fans Gorgonia ventalina and seawater. Aquat. Biol. 2010; 8:151-160. | Pdf

22. Toledo-Hernández C, Gulis V, Ruiz-Diaz CP, Sabat AM and Bayman P. When aspergillus hits the fan: disease transmission and fungal biomass in diseased versus healthy sea fans (Gorgonia ventalina). J. Fun. Ecol. 2012. | Article

23. Ainsworth TD, Kramasky-Winter E, Loya $Y$, Hoegh-Guldberg $O$ and Fine $M$. Coral disease diagnostics: What's between a Plague and a band? Appl. Environ. Microbiol. 2007; 73:981-992. | Article

24. Flynn KM and Weil E. Impact of the fungal disease aspergillosis on populations of the sea fan Gorgonia ventalina (Octocorallia, Gorgonacea) in La Parguera, Puerto Rico. Master Thesis, University of Puerto Rico, Mayagüez Puerto Rico.2008; 86.

25. Gateño D, Israel A, Barki $Y$ and Rinkevich B. Gastrovascular circulation in an Octocoral: Evidence of significant transport of coral and symbiont cells. Biol. Bull. 1998; 194:178-186. | Article

26. Hall-Spencer JM, Pike J and Munn CB. Diseases affect cold-water corals too: Eunicella verrucosa (Cnidaria: Gorgonacea) necrosis in SW England. Dis Aquat Organ. 2007; 76:87-97. | Article | PubMed

27. Mydlarz LD, Holthouse SF, Peters EC and Harvell CD. Cellular responses in sea fan corals: granular amoebocytes react to pathogen and climate stressors. PLoS One. 2008; 3:e1811. | Article | PubMed Abstract | PubMed Full Text

28. Olano CT and Bigger CH. Phagocytic activities of the gorgonian coral Swiftia exserta. J Invertebr Pathol. 2000; 76:176-84. | Article | PubMed

29. Couch CS, Weil E and Harvell CD. Temporal dynamics and plasticity in the cellular immune response of the sea fan coral Gorgonia ventalina. Mar. Biol. 2013; 160:2449-2460. I Article

30. Chen CY, He T, Mao XL, Friis TE, Qin RH and Jian YT. A novel xylene substitute for histotechnology and histochemistry. Biotech Histochem. 2010; 85:231-40. | Article | PubMed

31. Hauser J. Ausschaltung des xylols in der histologischen technik. Mikroskopie. 1952; 7:208-211.

32. Matthews JB. Influence of clearing agent on immunohistochemical staining of paraffin-embedded tissue. J Clin Pathol. 1981; 34:103-5. I Article | PubMed Abstract | PubMed Full Text

33. Efrony R, Atad I and Rosenberg E. Phage therapy of coral white plague disease: properties of phage BA3. Curr Microbiol. 2009; 58:139-45. | Article | PubMed

\section{Citation:}

Toledo-Hernández C, Torres-Vázquez II and SerranoVélez JL. Microwave-accelerated processing of coral tissue histology. J Histol Histopathol. 2014; 1:7. http://dx.doi.org/10.7243/2055-091X-1-7 